\title{
TEACHING PREFIXES AS PART OF TEACHING VOCABULARY BY USING FLIP-A-CHIP TO THE ELEVENTH GRADE STUDENTS OF SENIOR HIGH SCHOOL AISYIYAH 1 OF PALEMBANG
}

\author{
M. Bambang Purwanto \\ mbambangpurwanto@gmail.com
}

\section{Travel and Tourism Industry Program, Darussalam Polytechnic, Indonesia}

\begin{abstract}
The main problem of this study was "is it effective to use flipa-chip in teaching prefixes as part of teaching vocabulary to the eleventh grade students of senior high school Aisyiyah 1 of Palembang ?". The objective of this study was to find out whether or not flip-a-chip to teach prefixes as part of teaching vocabulary to the eleventh grade students of senior high school Aisyiyah 1 of Palembang. In this study the writer used experimental method. The population was the eleventh grade students of senior high school Aisyiyah 1 of Palembang. The samples were 32 students taken from the population of 202 students. In collecting data, the writer used a written test by using multiple choice test. The data were analyzed based on the result of pretest and posttest by using matched ttest formula. The mean score of the students in pretest was 66.95. The mean score of the students in posttest was 75.87. The effectiveness of this study was proved by the result of the calculation of matched t-test, which showed t-obtained (8.796) was higher than t-table (1.694). the alternative hypothesis $\left(\mathrm{H}_{\mathrm{a}}\right)$ was accepted and consequently the null hypothesis $\left(\mathrm{H}_{\mathrm{o}}\right)$ was rejected. In other words, it can be concluded that teaching the eleventh grade students' English prefixes by using flip-a-chip was effective.
\end{abstract}

Key Words: Teaching, Prefixes, Vocabulary, and Flip-A-Clip 
I. Introduction

According to Schmitt and McCarthy (1997:140), vocabulary is no longer a victim of discrimination in second language learning research, nor in language teaching. However, in learning English as a foreign language, many students have got difficulties in remembering the vocabulary because they are quite different from their daily language that is why learning vocabulary is not easy for them. Besides, the teacher rarely relates vocabulary teaching to the need of the students and the environment of the students themselves as well.

Teaching vocabulary is one way to improve the student's knowledge in order to be able to build a grammatical sentence and also teaching vocabulary is one difficult item complemented by teacher because many things should be concerned and it has to take good handling in order that students can understand what is the vocabulary itself.

Moreover, for making students are interested and motivated in learning vocabulary, the teacher should be able to choose a good strategy in teaching vocabulary. Furthermore, the teacher should be creative in teaching vocabulary so that it catches the student's attention and make them that they have learned. And teacher has to find an appropriate strategy that can be applied in order to make the learning vocabulary interesting for the students. One of the strategies is by using Flip A - Chip.

Flip - A - Chip is an appropriate strategy for students, and it promotes vocabulary developments, syllable recognition, and the comprehension of meaningful affixes and roots. This theory is introduced by Lee Mountain ( 2002:62-68 ). Jaya (2017) states that by using this strategy, learning vocabulary can help the students organizes new word and concept in relation to the familiar words. Then this strategy in learning vocabulary can help students to involve in the activity and requires student's participation, which enhances personal engagement in the activity and leads to deeper processing of word meaning. So, by using Flip-A-Chip strategy in learning vocabulary can make easy to remember new of word.

In this study, the writer investigates the effective of flip-a-chip as one of strategy in teaching vocabulary. Therefore, the writer does 


\section{ESTEEM: JOURNAL OF ENGLISH STUDY PROGRAMME \\ P-ISSN 2622-9323 \\ E-ISSN 2622-2213}

a research with the title "Teaching Prefixes as part of Teaching Vocabulary by Using Flip-a-chip to the eleventh Grade Students of Senior High School Aisyiyah 1 of Palembang".

\section{Literature Review}

\section{a. Definition of Flip-a-Chip}

Flip-a-chip is an appropriate strategy for students, and it promotes vocabulary development, syllable recognition, and the comprehension of meaningful affixes and root. This theory introduced by Mountain . Lee ( $2002: 62-68$ ).

According to Stuart (2011: 4) flip-a-chip strategy is a great way to promote students' vocabulary development, syllables, comprehension of meaningful affixes, and how to use context in composition.

\section{b. The Description of Flip-a-Chip}

As seen at

http:www.readwritenthink.org/classroo

m-resources/lesson/lesson

_view.asp?id=253.accessed on ( 23

February 2014), Using a box of poker chips or any hard circles that can easily be flipped, a permanent marker to write the words, and a selected vocabulary list, the students are

instructed by the teacher to write a different affix on each side of one chip, and write a different root on each side of another chip.

For Example : on the first chip , a student writes the affix $P R O$ on one side and $R E$ on the other side. Then on the second chip, the student writes the root $V O K E$ on one side and DUCE on the other. The student is then instructed to flip the two chips in the air. When they land, a word will be made. For example, the words made are provoke $(\mathrm{PRO}+\mathrm{VOKE})$, produce $(\mathrm{PRO}+$ DUCE ), revoke ( $\mathrm{RE}+\mathrm{VOKE})$, and reduce (re + duce ).

In conclusion, flip-a-chip are the strategies which build vocabulary affix and root. The flip-a-chip approach not only promoted students' vocabulary development but also helps the teach syllable, comprehension of meaningful affixes, and the use of context in composition.

\section{c. The Procedure of Teaching \\ Prefixes as part of Teaching}

Vocabulary by using Flip-a-chip

In teaching prefixes as part of teaching vocabulary by using flip-achip, there are three steps taken including pre-activities, whilstactivities, and post activities. 

a. pre-activities

- Greeting
a. Assalamualaikum
b. good morning

- After greeting, the teacher checks the attendance list.

- The teacher motivates the students to ask question, for example by asking the following question.

a. can you mention the kinds of word.

Misunderstanding

Unhappy

Replay

b. have you ever heard that?

- The teacher states the teaching objectives.

b. whilst-activities

- The teacher introduces the class about the list of prefixes.

- The teacher guides the students to give meaning words of prefixes.

- The teacher describes the students of meaning of the words.

- The teacher prepares a sample flip-a-chip packet two chips one chip with different prefix and root each side.
- The teacher demonstrates how to flip the chip and create the word.

- The teacher, instruct students to work with partners to create packets and the file cards to accompany them. Have them check the dictionary for spelling and usage.

- The teacher asks the students to collect their list.

c. post-activities

- The teacher gives the students a chance to tell their own problem about the subject matter if they have.

- The teacher reviews the materials.

\section{Research Procedures}

In this study, the writer will use pre-experimental method with one group pretest-posttest design. According to Fraenkel and Wallen (1993:236), in the one group, a single group is measured or observed not only after being exposed to a treatment of some sort, but also before. A diagram of this design is as follow:

$\begin{array}{lll}\mathrm{O}_{1} & \mathrm{X} & \mathrm{O}_{2}\end{array}$

Pretest treatment posttest

Where : 
$\mathrm{O}_{1}$ : The Test before Experiment (pretest)

$\mathrm{O}_{2}$ : The Test after Experiment (posttest)

$\mathrm{X}$ : The Treatment by Using flipa-chip

\section{a. Population}

Sugiono (2013:117) state that population is a generalization area consisting of object or subject that has a quality and specific criteria which is decided by the researcher to observe and then to put the conclusion of it. The population of this study is the eleventh grade students of Senior high school Aisyiyah 1 of Palembang in the academic year of 2018/2019. The number of the population of this research is 202 students as shown in Table below.
THE POPULATION OF THE STUDY

\begin{tabular}{|c|c|c|}
\hline No & Class & $\begin{array}{c}\text { The } \\
\text { number } \\
\text { of } \\
\text { students }\end{array}$ \\
\hline 1 & X1 IPA & 45 \\
\hline 2 & X1 & 32 \\
IPS1 & \\
\hline 4 & X1 & 32 \\
& IPS2 & \\
\hline 5 & X1 & 32 \\
\hline 6 & IPS4 & \\
\hline & X1 & 31 \\
\hline & Jumlah & 202 \\
& Students \\
\hline
\end{tabular}

(source: Senior High School

Aisyiyah 1 Palembang in the

Academic year of 2018/2019)

\section{b. Sample}

According to Sugiono (2013:118), sample is a part of amount and character of a population. This study, used convenience non random sampling. According to Fraenkel and Wallen (1990:75), “convenience sample is a group of individuals (conveniently) are available for study". 


\section{ESTEEM: JOURNAL OF ENGLISH STUDY PROGRAMME \\ P-ISSN 2622-9323 \\ E-ISSN 2622-2213}

The teacher of English at the school determined the class to be taken as the sample, namely XI IPS2. The number of the sample was 32 students shown in table below.

\section{THE SAMPLE OF STUDY}

\begin{tabular}{|c|c|c|}
\hline NO & CLASS & STUENTS \\
\hline 1. & XI & 32 \\
IPS2 & \\
\hline
\end{tabular}

(source : Senior High School Aisyiyah

1 of Palembang in the Academic year of 2018/2019)

\section{c. The Technique for Collecting} the Data

In collecting the data, the writer used a test. Arikunto (2010 : 150 ) defines that a test is question or exercise or other ways to measure skills, knowledge , intelligence, ability , or talents of individual or group. The writer used a written test that presented in the form of pre-test and post-test. A pre-test has given before doing the experiment and post-test has given after doing teaching experiment. She will give the same material for the pretest and post-test in the form of multiple-choice test. After that, the results of the two tests compared to know the students' achievement in teaching and learning process.

\section{Finding and Interpretations}

- Findings

From this study, it was found that teaching the eleventh grade students English prefixes by using flipa-chip was effective. Then, it was also found that the average scores of the students' pretest was 66.81 . the highest score 90 that was reached by one student and the lowest score was 42.5 that was reach by one student. The total scores of the pretest 2138 .

In the post-test, the average scores of the students was 75.87. the highest score was 97.5 reached by one students. The lowest score was 52.5 reached by one student. The total scores of the post-test was 2428 .

Based on the scores of the pretest and posttest above, the writer found that the result of matched t-test was 8.796. In the other hand, the significances level was 0.05 with $\mathrm{df}=32$, and the critical value of the table was 1.694. It indicates that " $\mathrm{t}$ " obtained is higher than " $\mathrm{t}$ " table. It also indicates that the null hypothesis (Ho) was rejected and the alternative hypothesis (Ho) was accepted. It means that teaching prefixes as part of teaching vocabulary by using flip-achip to the eleventh grade students of 


\section{ESTEEM: JOURNAL OF ENGLISH STUDY PROGRAMME \\ P-ISSN 2622-9323 \\ E-ISSN 2622-2213}

Senior High School Aisyiyah 1 of Palembang was effective.

\section{- Interpretations}

After analyzing the students' scores in the pretest and post-test, and knowing the result of the experiment, the writer that in teaching prefixes as part of teaching vocabulary by using flip-a-chip to the eleventh grade students of Senior High School Aisyiyah 1 of Palembang was effective.

The writer taught the students using flip-a-chip as the treatment. The first the writer explained to the students about English prefixes, reminded about vocabulary, introduced the students about flip-a-chip, when the students understood the writer asked the students to practicing English prefixes by using flip-a-chip.

And then, from the students' scores, the average score in pre-test and post-test in the experimental class of prefixes the matched $t$-test was 8.796 it is higher than 1.694 , as its critical value. It means that teaching prefixes by using flip-a-chip enable the students to get better scores.

There are factors that caused the scores of the student in the post-test higher than the scores of the student in the pre-test, According to Lee Mountain ( 2002:62-68 ). He stately that by using this strategy, learning vocabulary can help the students organizes new word and concept in relation to the familiar words. Then this strategy in learning vocabulary can help students to involve in the activity and requires student's participation, which enhances personal engagement in the activity and leads to deeper processing of word meaning. So, by using Flip-A-Chip strategy in learning vocabulary can make easy to remember new of word.

\section{Conclusion}

Based on the research of the findings and interpretation in the previous chapter, the writer find out that in teaching prefixes as part of teaching vocabulary by using flip-achip to the eleventh grade students of senior high school Aisyiyah 1 of Palembang was effective. The average scores of the students in pretest was 66.81 and the average score of the students in posttest was 75.87 , and the result of t-test 8.796 was higher than the value of t-table 1.694 besides that by using flip-a-chip could motivate the students to take a part in teaching learning activities more active in class. 
And then the students can be understood and more focused on the teacher explanation, the students can understand the material because the teacher explained the material clearly as possible.

It means that the research hypothesis (Ha) was accepted. So it can be conducted that teaching prefixes as part of teaching vocabulary by using flip-a-chip to the eleventh grade students of senior high school Aisyiyah 1 of Palembang is effective to improve the students' achievement. Therefore, it is believed that teaching prefixes by using flip-a-chip can be considered as one technique to be used.

\section{References}

Arikunto, Suharsimi. 2010. Prosedur Penelitian : Suatu Pendekatan Praktek. Jakarta Rhenika Cipta

Fraenkel, Jack R and Norman E Wallen. 1993. How to Design and Evaluate Research in Education. San Fransisco: Mc Graw-Hill Publishing Company.

Jaya, A. 2017. The Influence of Teachers' Questioning
Strategies on the Eleventh Grade Students' Speaking Achievement at SMKN 1 Palembang.Jambi-English Language Teaching. 2 (1).

Lee Mountain, "Flip-A-Chip to Build Vocabulary," Journal of Adolescent an adult Literacy 46, no.1 (September 2002) : 6268.

Redman, Stuart. 1997. English vocabulary in use : preintermediate and intermediate : Cambridge University Press.

Schmitt, Norbert and Michael McCharty. 1997. Vocabulary :Description Acquisition and Pedagogy. Cambridge : University Press.

Sugiono.2013. Metode Penelitian Pendidikan. Bandung : ALFABETA. 